\title{
Diskursus Muhkam dan Mutasyabih dalam Tafsir
}

\author{
Fikria Najitama \\ Institut Agama Islam Nahdlatul Ulama (IAINU) Kebumen \\ e-mail: fikrianajitama@gmail.com
}

\begin{abstract}
Abstrak
Dalam diskursus ilmu tafsir, muhkam dan mutasyabih merupakan salah satu instrumen penting yang mengandung kontroversi dikalangan para ahli tafsir. Dalam sejarahnya, kajian mengenai ayat muhkam dan mutasyabih sudah menjadi bahan pembicaraan dikalangan mufassirin dari zaman dahulu hingga saat ini. Dari opini yang muncul terkait dengan persoalan muhkam dan mutasyabih, dapat dikategorikan menjadi tiga: Pertama, opini yang memahami persoalan muhkamdan mutasyabih dengan lebih menekankan pada aspek pemahamannya. Opini ini bisa juga disebut dengan teori pemahaman. Kedua, opini yang lebih menekankan pada aspek pengamalannya. Opini model ini mungkin juga dapat disebut dengan teori pengamalan. Ketiga, opini yang lebih menekankan pada elaborasi internal al-Qur'an. Opini ini bisa juga disebut sebagai teori isi. Ketiga opini tersebut merupakan implikasi dari pembacaan terhadap teks-teks al-Qur'an.
\end{abstract}

Kata Kunci: muhkam, mutasyabih, tafsir

\section{A. Pendahuluan}

Dalam kajian al-Qur'an dan tafsir, muhkam dan mutasyabih merupakan salah satu instrumen penting yang mengandung kontroversi dikalangan para ahli tafsir. Dalam sejarahnya, kajian mengenai ayat muhkam dan mutasyabih sudah menjadi bahan pembicaraan dikalangan mufassirin dari zaman dahulu hingga saat ini. Setiap generasi melakukan kajian yang mengakibatkan munculnya ilmu-ilmu baru yang belum tergali pada masa sebelumnya. Ketika 
ingin menjelaskan pengertian mutasyabih, pembahasannya tidak sempurna sebelum menjelaskan hal yang bersangkutan dengannya yaitu muhkam. Muhkam dan mutasyabih adalah dua istilah yang saling bergandengan dan tidak bisa dipisahkan antara keduanya.

Kajian muhkam dan mutasyabih itu setidak-tidaknya menimbulkan dua persoalan: Pertama, perbedaan pandangan tentang kategori ayat muhkam dan ayat mutasyabih. Karena perbedaan ini, maka ada ayat-ayat yang bagi suatu kelompok umat Islam bersifat muhkamat, namun bagi kelompok lain bersifat mutasyabihat. Kedua, perbedaan pandangan tentang boleh atau tidaknya melakukan ta'wil terhadap ayat-ayat yang mutasyabihat. Sebagian ahli tafsir membolehkannya, sehingga dalam memahami ayat-ayat mutasyabihat itu, harus dilakukan interpretasi dibalik ungkapan-ungkapan lahiriah. Sebagian lagi yang tidak membolehkannya, berpendapat dalam memahami ayat-ayat itu kita harus berhenti pada makna-makna teks.

Tulisan ini akan berusaha memaparkan opini terkait dengan persoalan mubkam dan mutasyabih. Tidak hanya dari para pemikir klasik, tetapi juga akan mengetengahkan beberapa opini dari para pemikir kontemporer. Selain itu, tulisan ini juga akan mencoba mengklasifikasi pendapat tersebut dalam kerangka pendekatan masing-masing tokoh.

\section{B. Makna Muhkam-Mutasyabih}

Term muhkam dan mutasyabih merupakan istilah yang berasal dari bahasa Arab. Menurut ahli tafsir, muhkam secara etimologi berasal dari kata al-itqan dan juga dari kata al-ihkam. Berasal dari kata al-itqan seperti lafal أحكم الامر yang berarti mengokohkan sesuatu, ${ }^{1}$ atau seperti lafal إحكم الكلام yang berarti mengokohkan perkataan dengan memisahkan berita yang benar dari yang salah, atau urusan yang lurus dari yang sesat. ${ }^{2}$ Muhkam juga dapat berasal dari kata al-ihkam seperti lafal حكمت الدبه واحكمت berarti saya menahan binatang itu. al-Hukm berarti memutuskan dua perkara, maka kata hakim adalah orang yang mencegah kezaliman dan memisahkan antara dua pihak yang

\footnotetext{
1 Muhammad Bakar Isma'il, Dirasat fi 'Ulum al-Qur'an, cet. ke-1, (Kairo: Dar al-Manar, 1991), hlm.207-208.

2 Manna' al-Qattan, Mabahis fi 'Ulum al-Qur'an, (t.p.: Mansurat al-'Isri al-Hadis, t.t.), hlm. 215.
} 
bersengketa. ${ }^{3}$ Pengertian tersebut juga dapat dihubungkan dengan makna menetapkan ketentuan-ketentuan, yang dengannya seseorang tercegah dari berbuat sesuatu di luar ketentuan tersebut, dan ketentuan itu harus sesuatu yang jelas dan tegas. ${ }^{4}$

Adapun term mutasyabih secara etimologi berasal dari kata at-tama'sil. ${ }^{5}$ Mutasyabih juga berasal dari kata tasyabuh, yang bisa bermakna sesuatu dari dua hal menyerupai yang lain. Bila diderivasikan, syubhah ialah keadaan dimana salah satu dari dua hal tidak dapat dibedakan dengan yang lain karena ada kemiripan. Menurut az-Zarqani, mutasyabih juga bisa berarti samar, yang juga mengandung konotasi yang biasanya membawa pada ketidakpastian dan ragu (iltibas). ${ }^{6}$ Timbulnya keraguan tersebut tidak lain dikarenakan miripnya dua benda yang diamati tersebut, sehingga tidak dapat, atau sulit sekali menentukan perbedaannya. ${ }^{7}$ Sebagai misal, firman Allah: ${ }^{8}$ وأتوابه متشابه . Ayat ini berarti sebagian buah-buah di surga itu serupa dengan sebagian yang lain dalam hal warna, tidak dalam hal rasa dan hakikat. ${ }^{?}$

\section{Beberapa Pendapat Tentang Muhkam-Mutasyabih}

Dalam kajian ilmu tafsir, persoalan muhkam dan mutasyabih telah memunculkan banyak pendapat dan opini dikalangan ahli tafsir. Al-Qur'an telah memuat kedua terminologi tersebut yaitu:

$$
\text { هوالذى أنزل عليك الكتاب منه ايآت مهكمات هن أم الكتاب وأخر }
$$

Ibid.

4 Nashruddin Baidan, Wawasan Baru Ilmu Tafsir, cet. ke-1, (Yogyakarta: Pustaka Pelajar, 2005), hlm. 152.

Muhammad Bakar Isma’il, Dirasat..,hlm. 207.

Muhammad 'Abdul 'Azim az-Zarqani, Manahil 'Irfan fi 'Ulum al-Qur'an, cet. ke-1, (Beirut: Dar al-'Ilmiyyah, 2003), hlm. 423.

Nashruddin Baidan, Wawasan..., hlm. 153.

QS. al-Baqarah (2): 25.

Manna’ al-Qattan, Mabahis...,hlm. 215.

10 QS. Ali ‘Imran (3): 7. 
Ayat tersebut memuat istilah muhkamat dan mutasyabihat dalam posisi bertentangan. Istilah pertama berkonotasi pada sesuatu yang jelas dan terang dalalahnya, sementara yang kedua menunjukkan kepada sesuatu yang samar dan kabur dalalahnya. Dalam kerangka ini, kemudian muncul pertanyaan apakah al-Qur'an seluruhnya muhkam, atau semuanya mutasyabih atau mengandung mubkamdan mutasyabih secara bersamaan? Pertanyaan ini kemudian memunculkan tiga pendapat: ${ }^{11}$ Pertama, al-Qur'an mengandung muhkamdan mutasyabih. Asumsi ini berlandaskan pada firman Allah:

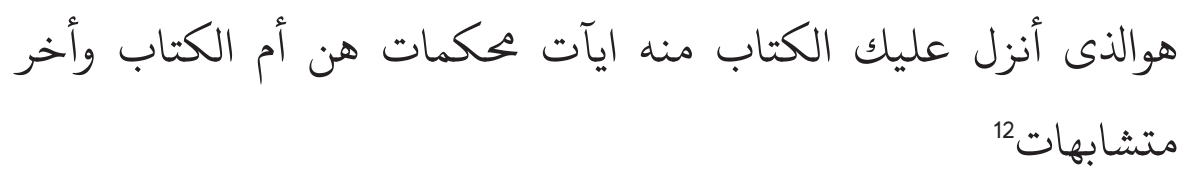

Ayat tersebut secara jelas memuat istilah muhkamat dan mutasyabihat. Hal ini secara jelas pula mengungkapkan pola yang terkandung dalam alQur'an.

Kedua, bahwa al-Qur'an seluruhnya bersifat muhkam. Dasar dari asumsi ini berasal dari firman Allah:

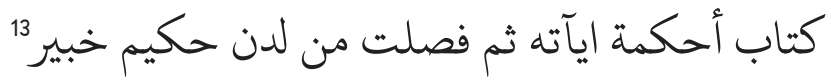

Asumsi ini juga bermakna bahwa al-Qur'an seluruhnya muhkamdalam artian kata-katanya tetap, fasih, dan membedakan yang hak serta yang batil, dan antara yang benar dan yang dusta. Menurut al-Qattan, inilah yang dimaksud dengan al-ihkam al-'amm atau mubkam dalam artian umum. ${ }^{14}$

Ketiga, bahwa al-Qur'an seluruhnya bersifat mutasyabih. Dasar dari asumsi ini berasal dari firman Allah:

11 Amir 'Abdul Aziz, Dirasat fi 'Ulum al-Qur'an, (Beirut: Dar al-Furqan, 1983), hlm. 179-180. lihat juga, Subhi as-Salih, Mabahis fi 'Ulum al-Qur'an, cet. ke-7, (Beirut: Dar al-'Ilm al-Malayin, 1977), hlm. 281-282. Muhammad 'Abdul 'AzIm az-Zarqani, Manahil..., hlm. 423.

12 QS. Ali ‘Imran (3): 7.

13 QS. Hud (11): 1.

14 Manna’ al-Qattan, Mabahis...,hlm. 215. Bandingkan, Muhammad Bakar Isma’il, Dirasat...,hlm. 207. 


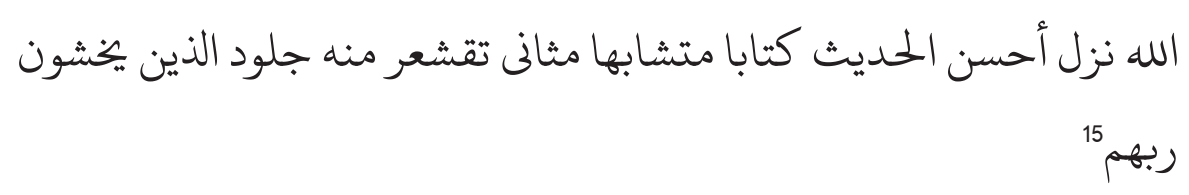

Maksud dari asumsi ini adalah al-Qur'an itu sebagian kandungannya serupa dengan sebagian yang lain dalam kesempurnaan dan keindahannya, dan sebagian membenarkan sebagian yang lain serta sesuai pula maknanya. Inilah yang kemudian dinamakan dengan at-tasyabuh al-'amm atau mutasyabih dalam artian umum. ${ }^{16}$

Dari ketiga pendapat tersebut nampaknya asumsi pertamalah yang kemudian dibahas secara lebih mendalam oleh para ahli tafsir. Persoalan yang kemudian muncul dari asumsi tersebut adalah menyangkut pengertian muhkamdan mutasyabih dan bagaimana cara berinteraksi dengan ayatayat muhkamat-mutasyabih. Persoalan ini kemudian memunculkan banyak pendapat.

Ibn 'Abbas berpendapat bahwa ayat-ayat al-Qur'an yang muhkamat adalah yang menjelaskan apa-apa yang dihalalkan dan diharamkan, yang belum dibatalkan dan yang harus diimplementasikan (mubayyinat bi al-halal wa alharam lam tunsakh yumalu biha). Contoh dari kategori ini adalah ayat-ayat al-Qur'an yang mengandung prinsip bagi manusia, seperti anti kemusyrikan, hormat dan berbakti pada orang tua, larangan membunuh, larangan berzina dan lain sebagainya. ${ }^{17}$ Sedangkan ayat mutasyabihat adalah ayat-ayat yang mengandung huruf terpisah -seperti alif-lam-mim- yang berada pada awal surat al-Qur'an dan dikenal dengan fawatih al-suwar. Selain itu ayat-ayat yang sudah dibatalkan dan yang tidak dilaksanakan juga termasuk dalam kategori mutasyabihat. ${ }^{18}$

Al-Qaradawi mempunyai pendapat yang berbeda. Menurutnya, yang dimaksud dengan muhkamadalah ayat yang jelas dengan sendirinya,

\footnotetext{
15 QS. az-Zumar (23): 23.

16 Manna’ al-Qattan, Mabahis...,hlm. 215. Bandingkan, Muhammad Bakar Isma’il, Dirasat...,hlm. 207.

17 Lebih lanjut lihat, Syamsu Rizal Panggabean, "Makna Muhkam dan Mutasyabih dalam al-Qur'an" dalam 'Ulumul Qur'an, vol. II, (Jakarta: LSAF, 1990), hlm. 47.

Ibid.
} 
menunjukkan pada maknanya dengan terang, dan tidak memperlihatkan kesamaran baik dari segi lafal ataupun dari segi makna. Sedangkan yang dimaksud dengan mutasyabihadalah lafal yang sukar dalam penafsirannya karena adanya keserupaan dengan yang lain, baik dari segi lafal ataupun makna. ${ }^{19}$ Kemudian dengan merujuk pada ar-Ragib, al-Qaradawi menjelaskan bahwa persoalan ayat diklasifikasikan menjadi tiga macam, yaitu: 1) muhkam secara mutlak; 2) mutasyabih secara mutlak; 3) mubkam dalam satu segi dan mutasyabih dari segi yang lain. Adapun mutasyabih menurut al-Ragib dikategorikan menjadi tiga, yaitu:

1. Mutasyabih dari segi lafal an sich. Dalam hal ini mutasyabih lafal dibagi menjadi dua yaitu, pertama lafal yang merujuk pada lafal yang jauh atau istirak. Kedua, lafal yang merujuk pada jumlah kalam murakab (majemuk).

2. Mutasyabihdari segi makna an sich. Mutasyabih ini terkait dengan sifat-sifat Allah, sifat-sifat hari kiamat dan berbagai sifat yang tidak tergambarkan oleh indera kita.

3. Mutasyabih dari segi lafal dan makna. Kategori ini dapat dibagi menjadi lima yaitu: pertama, segi kamiyah seperti 'umum dan khusus. Kedua, dari segi kaifyah seperti wajib dan sunah. Ketiga, dari segi zaman seperti nasikh dan mansukh. Keempat dari segi makan seperti perkara yang berhubungan dengan ibadah jahiliyah dan yang telah ada di Arab. Kelima, dari segi syarat yaitu sesuatu yang menjadikan perbuatan itu baik atau cacat. ${ }^{20}$

Pendapat yang lain datang dari al-Qattan. Ia menjelaskan bahwa ayat muhkam adalah ayat yang mudah diketahui maksudnya, mengandung satu segi pemahaman (wajah) dan maksudnya dapat diketahui secara langsung. Contoh ayat muhkam adalah ayat-ayat nasikh, ayat-ayat tentang halal dan haram, hudud, kewajiban, janji dan ancaman. Sedangkan ayat mutasyabih adalah ayat yang maksudnya hanya diketahui oleh Allah, mengandung banyak

19 Yusuf al-Qaradawi, Kaifa Natáamalu máa al-Qur'an al-'Azim, cet. ke-3, (Kairo: Dar asy-Syuruq, 2000), hlm. 267.

20 Ibid. al-Qaradawi dalam tulisannya tidak mengeksplorasi secara luas pemikiran al-Ragib, khususnya terkait dengan aplikasi ataupun model dari kategorisasi tersebut. 
segi pemahaman (wajah) dan memerlukan penjelasan dengan merujuk pada ayat-ayat lain. ${ }^{21}$

'Ali bin Abi Talhah memberikan pengertian muhkam dan mutasyabih dengan lebih terperinci. Menurutnya ayat-ayat muhkamat adalah: 1) ayatayat yang membatalkan ayat-ayat lain; 2) yang menghalalkan; 3) yang mengharamkan; 4) yang berisi ketentuan-ketentuan; 5) yang mengandung kewajiban-kewajiban; 6) yang diimani dan diamalkan (nasikhuhu wahalaluhu wa haramuhu wa faraiduhu wa ma yumanu bihi wa ma yumalu bibi). Dalam hal ini, yang termasuk dalam kategori mubkamadalah rincian-rincian hudud, faräid, dan yumanu bihi dalam pengertian mubkamat. Sedangkan ayat mutasyabihat adalah: 1) ayat-ayat yang telah dibatalkan; 2) yang dipertukarkan antara yang terdahulu dengan yang belakangan; 3) yang berisi parabel; 4) yang mengandung sumpah; 5) yang diimani tapi tidak diamalkan (mansukhubu wa muqaddamuhu wa muakharuhu wa amsilatuhu wa aqsamuhu wa ma yumanu bihi wa la yumalu bihi).22

Abu Zaid mempunyai pemahaman yang lebih ringkas. Menurutnya ayat muhkammerupakan ayat yang jelas dan nyata serta tidak memerlukan ta'wil, sementara ayat mutasyabih adalah ayat yang ambigu dan membutuhkan ta'wil. ${ }^{23}$ Pendapat Abu Zaid ini selaras opini yang digunakan oleh Mu'tazilah. Menurut Mu'tazilah ayat muhkam merupakan ayat yang langsung dapat dicerna oleh akal dengan hanya melihat teksnya. Sementara ayat yang tidak dapat langsung dicerna oleh akal dikategorikan sebagai mutasyabih. ${ }^{24}$

Sedangkan Muhammad Syahrur memiliki pembacaan yang berbeda mengenai persoalan muhkam-mutasyabih. Dengan berpijak pada QS. Ali 'Imran (3): 7, Syahrur berpendapat bahwa al-Qur'an tidak hanya memuat dua klasifikasi yaitu muhkamdan mutasyabih, namun juga memuat klasifikasi ketiga, yaitu ayat yang tidak mubkamdan tidak mutasyabih(la mubkamwa la

21 Manna’ al-Qattan, Mabahis...,hlm. 216.

22 Syamsu Rizal Panggabean, "Makna Muhkam..., hlm. 47.

23 Nasr Hamid Abu Zaid, Tekstualitas al-Qur'an, Kritik Terhadap Ulumul Qur'an, terj. Khoiron Nahdliyyin, (Yogyakarta: LKiS, 2002), hlm. 221.

24 Untuk lebih lanjut mengenai kajian ini, lihat, Nasr Hamid Abu Zaid, Menalar Firman Tuhan Wacana Majaz dalam al-Qur'an Menurut Mu'tazilah, terj. Abdurrahman Kasdi dan Hamka Hasan, cet. ke-1, (Bandung: Mizan, 2003), hlm. 241. 
mutasyabih). ${ }^{25}$ Menurutnya, ayat mubkama dalah kumpulan ayat-ayat yang terangkum dalam istilah umm al-kitab, yaitu ayat-ayat yang memuat penjelasan mengenai hukum, norma-norma perilaku manusia, ibadah, hubungan sosial dan ahlak. Sedangkan mutasyabih adalah seluruh kandungan al-Kitab selain yang muhkamat dan tafsil al-kitab, yaitu ayat-ayat yang termasuk dalam kategori al-qur'an dan al-sab al-masani. Sedangkan ayat yang tidak mubkam dan tidak mutasyabih adalah yang termasuk dalam kelompok tafsil al-qur'an. Kategori ini terbagi menjadi dua pengertian, yaitu, pertama, dimaknai sebagai ayat-ayat yang menjelaskan (posisi) kandungan al-Kitab, seperti QS. Ali 'Imran (3): 7. Kedua, berarti ayat-ayat al-qur'an yang menjadi pemisah bagi ayat-ayat muhkamat dalam urutan tartib al-mushaf. ${ }^{26}$

Adapun Rizal Panggabean dalam hal ini mempunyai pendapat yang berbeda dengan para pendahulunya. Pemahaman Rizal Panggabean menarik untuk dicatat. Dia menolak pemikiran para ahli tafsir terdahulu yang cenderung memahami muhkam- mutasyabih hanya sebagai istilah teknis al-Qur'an, dan tidak menukik dengan mencari bukti-bukti internal al-Qur'an terhadap berbagai makna yang ditawarkannya. Dengan cermat Rizal Panggabean mengeksplorasi pengertian masani dengan mencari bukti-bukti internal alQur'an. Dari penelusurannya, frase sab'an min al-masani dalam al-Qur'an merujuk pada tujuh kisah yang terdapat dalam al-Qur'an, yaitu: 1) kisah Musa dan pengikutnya; 2) kisah Ibrahim dan pengikutnya; 3) kisah Nuh dan pengikutnya; 4) kisah Hud dan pengikutnya; 5) kisah Shalih dan pengikutnya; 6) kisah Luth dengan kaumnya; 7) kisah Syu'aib dan pengikutnya. Dari eksplorasi inilah kemudian dia merumuskan bahwa ayat-ayat mutasyabihat adalah ayat-ayat yang berkaitan dengan wahyu (al-kitab) yang diterima Muhammad Saw, yang merujuk pada kisah-kisah pengazaban kaum para nabi terdahulu yang menolak mereka dan ajaran-ajarannya. Sedangkan ayat-ayat muhkamat adalah ayat-ayat yang merujuk pada ketentuan-ketentuan, atau

\footnotetext{
25 Menurut Syahrur, ayat 7 surat Ali 'Imran menegaskan bahwa al-Kitab selain yang muhkamat dan mutasyabih juga terdapat yang "lain" yaitu la muhkam wa la mutasyabih. Dengan demikian, kitab al-nubuwwah meliputi ayat-ayat yang klasifikasi mutasyabih dan la muhkam wa la mutasyabih, sedangkan al-risalah meliputi ayat-ayat dalam klasifikasi muhkamat. Lihat, Muhammad Syahrur, al-Kitab wa al-Qur'an: Qira'ah Mu'asirah, (Damaskus: al-Ahaly, 1990), hlm. 55-56.

26 Untuk lebih lanjut lihat, ibid., hlm. 55-57.
} 
aturan-aturan yang diwahyukan untuk kebaikan umat manusia. ${ }^{27}$

Dari opini-opini tersebut dapat dicatat bahwa pendapat yang muncul dalam memandang persoalan muhkam-mutasyabih mempunyai kerangka yang berbeda-beda. Namun kalau diklasifikasikan, perbedaan tersebut dapat dikategorikan menjadi tiga macam. Pertama, pendapat yang berupaya memandang persoalan mubkam-mutasyabih dari sudut pemahaman terhadap ayat-ayat. Poin inti dalam pendapat ini adalah wujud teks ayat-ayat alQur'an, apakah dapat langsung dipahami atau tidak. Bila bisa langung dapat dipahami, maka dapat diklasifikasikan sebagai muhkam. Namun bila tidak dapat langsung dipahami, dan membutuhkan ta'wil, maka bisa diklasifikasikan dalam mutasyabih. Opini yang bisa dikategorikan dalam kelompok ini adalah opini al-Qaradawi, al-Qattan, ar-Ragib, Abu Zaid, dan Mu’tazilah.

Kedua, pendapat yang lebih menekankan pada isi yang ada dalam teks ayat-ayat al-Qur'an. Dalam hal ini, poin inti dari pemahaman ini berpijak pada kandungan teks ayat-ayat al-Qur'an. Pemikir yang dapat dikategorikan dalam kelompok ini adalah Ibnu Abbas, 'Ali bin Abi Talhah, Syahrur dan Rizal Panggabean.

Ketiga, pendapat yang berupaya melihat dari perspektif aplikasi perintah (pengamalan) ayat-ayat al-Qur'an. Titik pijak dari pendapat ini terletak pada pengamalan ayat. Menurut az-Zarqani, pendapat as-Suyuti termasuk dalam kategori ini. ${ }^{28}$ Selain itu, 'Ali bin Abi Talhah juga bisa dikategorikan dalam kelompok ini.

\section{Problem Penafsiran terhadap Muhkam-Mutasyabih}

Mayoritas ulama mengakui eksistensi muhkam dan mutasyabih yang ada dalam al-Qur'an. Dengan keberadaannya tersebut, hal ini kemudian memunculkan persoalan, yaitu bagaimana cara berinteraksi dengan ayat-ayat muhkamdan mutasyabih? Ayat-ayat muhkamat yang ada dalam al-Qur'an tidak memunculkan banyak polemik. Mayoritas ahli tafsir mempunyai kesamaan persepsi dalam persoalan ini. Akan tetapi terkait dengan ayat-ayat mutasyabihat, khususnya ayat-ayat yang berkenaan dengan sifat-sifat Tuhan,

27 Lihat, Syamsu Rizal Panggabean, "Makna Muhkam..., hlm. 48-53.

28 Muh\{ammad 'Abdul 'Azim az-Zarqani, Manahil ..., hlm. 426-427. 
para ahli tafsir berbeda pendapat. Ada dua pendapat yang muncul terkait dengan persoalan ini, yaitu:

Pertama, bahwa tidak diperbolehkannya ta'wil terkait dengan ayat-ayat mutasyabihat. Kelompok ini biasanya disebut dengan kelompok salaf. Bagi kelompok ini, ayat-ayat mutasyabihat diterima dan dipercayai begitu saja secara apriori, dan menyerahkan saja maksud kandungan ayat kepada Allah. Subhi as-Salih memberi gambaran mengenai hal ini dengan mengambil kisah Imam Malik. Suatu ketika Imam malik ditanya oleh seseorang mengenai lafal di dalam ayat استواء. Kemudian Imam Malik menjelaskan "bahwa persoalan bahwa Allah استوش استواء العتوش jelas, tapi mengenai bagaimana caranya tidak diketahui, dan pertanyaan mengenai hal tersebut merupakan bid'ah. Saya mengira kamu seorang yang jahat, usir dia dari majlisku”. Imam Malik kemudian mengusir orang tersebut dari majlisnya. ${ }^{29}$

Baidan mencatat, bahwa sikap Imam Malik yang terasa kaku dan keras dalam menghadapi pemikiran-pemikiran yang tumbuh berkenaan dengan pemahaman dan penafsiran ayat-ayat mutasyabihat itu, pada hakikatnya melanjutkan apa yang dianut oleh para sahabat dan tabiin sebelumnya. Di mana pada umumnya mereka menerima dan mengimani saja apa yang diinformasikan al-Qur'an dan hadis, tanpa mempertanyakan lagi, sekalipun informasi tersebut kadang-kadang tidak masuk akal. ${ }^{30}$ Sikap ini juga masih nampak dari opini yang ditawarkan oleh para ahli tafsir, yaitu dengan berpendapat bahwa ayat-ayat mutasyabihat merupakan ayat yang yumanu bihi wa la yumalu bihi. ${ }^{31}$

Kedua, bahwa penggunaan ta'wil diperbolehkan dalam melakukan pembacaan terhadap ayat-ayat mutasyabihat. Kelompok ini biasanya disebut dengan kelompok khalaf. Kelompok ini terbagi menjadi dua macam. Pertama, yang mencoba melakukan ta'wil atas ayat-ayat mutasyabihat sesuai dengan sifatsifat yang diterima (dari-Nya) tanpa diketahui maksudnya secara pasti. Model ini dipelopori oleh Abu Hasan al-Asy'ari. ${ }^{32}$ Kedua, yang mencoba melakukan ta'wil atas ayat-ayat mutasyabihat sesuai dengan makna atau sifat-sifat yang

29 Subhi as-Salih, Mabahis.., hlm. 284.

30 Nashruddin Baidan, Wawasan..., hlm. 162.

31 Sebagai misal, lihat deskripsi az-Zarqani mengenai opini ini. Muhammad 'Abdul 'Azim az-Zarqani, Manabil ..., hlm. 426-427..

32 Nashruddin Baidan, Wawasan..., hlm. 163. 
dimaklumi manusia. Dengan demikian, kelompok ini berusaha memalingkan makna yang terkandung dalam ayat-ayat mutasyabihat kepada makna yang dipahami manusia. Model ini dipelopori oleh Imam al-Haramain. ${ }^{33}$

Munculnya perbedaan dalam menyikapi ayat-ayat mutasyabihat tersebut, merupakan implikasi dari perbedaan pemahaman terhadap QS. Ali 'Imran (3): 7. Dalam ayat tersebut dinyatakan:

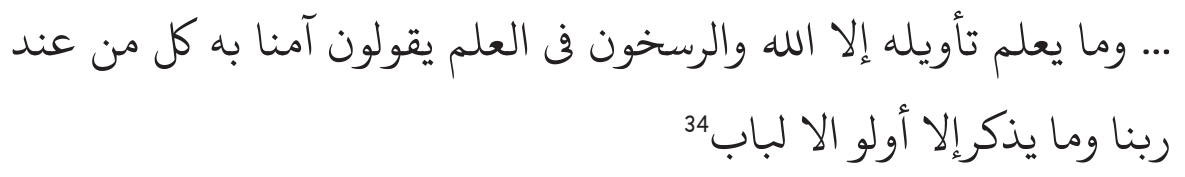

Ayat tersebut dalam sejarahnya mempunyai dua bentuk bacaan (qira'at). Bacaan pertama menetapkan waqaf pada lafal إلا الله. Dengan demikian, maka pemahaman ayat tersebut menjadi: “...tidak ada yang tahu ta'wilnya (ayat-ayat mutasyabihat itu) kecuali Allah sendiri; sedangkan orang-orang yang mendalam ilmunya menyatakan kami percaya, bahwa semua itu berasal dari sisi Tuhan kami...". Sedangkan bacaan yang kedua menempatkan waqaf pada lafal فى العلم dengan demikian, maka pemahaman ayat tersebut menjadi: “... tidak ada yang tahu ta'wilnya (ayat-ayat mutasyabihat itu) kecuali Allah dan orang-orang yang mendalam ilmunya; seraya menyatakan kami percaya bahwa semua itu berasal dari Tuhan kami... ".35

\section{E. Mutasyabihat dan Ta'wil}

Persoalan ta $^{\prime}$ il $^{\beta 6}$ terhadap ayat-ayat mutasyabihat dalam wacana penafsiran memang telah menjadi problem tersendiri. Bahkan dalam sejarahnya, persoalan ini telah menimbulkan perpecahan, bahkan pertikaian teologis dalam masyarakat Muslim. Nurcholish mencatat terkait dengan persoalan ta'wil sebagai berikut:

33 Subhi as-Salih, Mabahis..., hlm. 284. Menurut Baidan, dengan merujuk pada as-Suyuti, Imam Haramain memang pernah menganut pendapat tersebut, namun kemudian ia mencabut pendapatnya, dan pendapat barunya berubah menjadi lebih dekat dengan pemahaman kelompok salaf. Lihat, Nashruddin Baidan, Wawasan..., hlm. 164.

34 QS. Ali 'Imran (3): 7.

35 Mengenai persoalan perbedaan qira'ah ini, lihat, Nashruddin Baidan, Wawasan..., hlm. 167. Bandingkan, Manna' al-Qattan, Mabahis...,hlm. 218-219.

36 Mengenai persoalan makna ta’wil, lihat, Manna’ al-Qattan, Mabahis...,hlm. 218-219. 
Interpretasi metaforis atau ta'wil, ialah pemahaman atau pemberian pengertian atas fakta-fakta tekstual dari sumber-sumber suci (al-Qur'an dan al-Sunnah) sedemikian rupa, sehingga yang diperlihatkan bukanlah makna lahiriyah kata-kata pada teks sumber suci itu, tapi pada "makna dalam" (batin, inward meaning) yang dikandungnya. Metode pemahaman serupa itu (ta'wil) telah muncul sejak masa-masa dini sejarah Islam (jika tidak malah sejak masa Rasul Allah saw. sendiri, sebagaimana dikatakan kalangan Islam tertentu). Karena itu persoalan interpretasi metaforis ini mempunyai saham cukup besar dalam timbulnya perselisihan, kemudian perpecahan, di kalangan kaum Muslim. ${ }^{37}$

Walaupun persoalan ta'wil telah menimbulkan perselisihan, namun táwil merupakan instrumen penting dalam melakukan pembacaan terhadap teks. Dengan menggunakan táwil, maka akan memungkinkan untuk menemukan makna-makna yang baru dalam teks. Dalam bukunya, Abu Zaid menyatakan:

Berijtihad dalam melakukan ta'wil atas teks tidak dibedakan antara teks di bidang fiqh dan hukum dengan teks di bidang lainnya, sebab ijtihad didasarkan pada gerak "nalar" untuk menembus ke dalam teks. Jika perbedaan ta'wil dalam bidang fiqh termasuk sebagai "rahmat" dan untuk memberikan keringanan bagi umat, maka perbedaan ta'wil dalam bidang lain dari teks harus dipandang dari sudut pandang yang sama, khususnya apabila mu'awwil berpegang pada perangkat-perangkat analisis teks, dan tidak pada hawa nafsunya atau pendapat pribadinya. Mendekati teks dan berusaha mengungkapkan misteri-misterinya dimulai dengan pembacaan tingkat pertama, kemudian pembacaan dalam tingkatan analitis. Melalui pembacaan kedua ini akan terungkap kata-kata kunci” teks dan maknamakna sentralnya, dan melalui makna-makna sentral itu múawwil dapat mengungkapkan beberapa misteri teks. Teks selalu terbuka terhadap setiap pembacaan baru. ${ }^{38}$

Pendapat Abu Zaid tersebut penting untuk dicatat. Persoalan ta'wil haruslah dipandang sebagai ikhtiar dalam melakukan eksplorasi makna teks. Selain itu harus dipahami bahwa teks selalu menawarkan dan terbuka terhadap setiap pembacaan baru. Namun Abu Zaid memberi catatan, bahwa ta'wil terhadap ayat-ayat mutasyabihat haruslah dipahami berdasarkan ayat-ayat

\footnotetext{
37 Nurcholish Madjid, "Masalah Ta’wil Sebagai Metodologi Penafsiran al-Qur'an” dalam http://media. isnet.org/islam/Paramadina/Konteks/Takwil2.html. Akses, 28 November 2016.

38 Nasr Hamid Abu Zaid, Tekstualitas..., hlm. 301-302.
} 
muh\{kamat. Dalam hal ini ia memposisikan ayat-ayat muhkamat sebagai induk (backbone) teks, dan berfungsi sebagai kunci untuk melakukan penjelasan dan klarifikasi terhadap ayat-ayat mutasyabihat. ${ }^{39}$

Para penafsir mutaakhirin ${ }^{40}$ cenderung mengaplikasikan táwil dalam pembacaannya terkait dengan ayat-ayat mutasyabihat. Muhammad Asad misalnya, ia memaknai mutasyabihat sebagai ayat-ayat yang menggunakan redaksi-redaksi majazi (metaforis) dan memiliki makna simbolis. Oleh karena itu, pemahaman metaforis (ta'wil) harus digunakan agar tidak terjadi kekeliruan dalam memahami jiwa ajaran al-Qur'an. ${ }^{41}$

Dari uraian di atas, nampak bahwa táwil (khususnya terhadap ayatayat mutasyabihat) merupakan sebuah instrumen penting dan akan sangat membantu dalam memahami teks-teks al-Qur'an. Selain itu dengan melakukan eksplorasi mendalam terhadap teks al-Qur'an dengan ta'wil, akan lebih mendorong dalam pembumian al-Qur'an di tengah kehidupan modern dewasa ini, dan merespon problematika yang ada.

\section{F. Kesimpulan}

Dari opini yang muncul terkait dengan persoalan mubkam dan mutasyabih, dapat dikategorikan menjadi tiga: Pertama, opini yang memahami persoalan muhkam dan mutasyabih dengan lebih menekankan pada aspek pemahamannya. Opini ini bisa juga disebut dengan teori pemahaman. Kedua, opini yang lebih menekankan pada aspek pengamalannya. Opini model ini mungkin juga dapat disebut dengan teori pengamalan. Ketiga, opini yang lebih menekankan pada elaborasi internal al-Qur'an. Opini ini bisa juga disebut sebagai teori isi. Ketiga opini tersebut merupakan implikasi dari pembacaan terhadap teks-teks al-Qur'an.

Terkait dengan ayat-ayat mutasyabihat, kalau diteliti lebih jauh, sebenarnya para ahli tafsir tidak mempersoalkan penggunaan ta'wil terhadap ayat-ayat

39 Moch. Nur Ichwan, "al-Qur’an sebagai Teks (Teori Teks dalam Hermeneutik Qur’an Nasr Hamid Abu Zaid)” dalam Abdul Mustaqim dan Sahiron Syamsudin (ed). Studi al-Qur'an Kontemporer Wacana Baru Berbagai Metodologi Tafsir, (Yogyakarta: Tiara Wacana, 2002), hlm. 154-155.

40 Kategori ini merujuk pada pendapat Subhi as-Salih, Lihat, Subhi as-Salih, Mabahis..., hlm. 284.

41 Quraish Shihab, Membumikan al-Qur'an, Fungsi dan Peran Wahyu Dalam Kehidupan Masyarakat, cet. ke-23, (Jakarta: Mizan, 2002), hlm. 94-95. 
tersebut. Imam Malik nampaknya juga tidak mempersoalkan penggunaan ta'wil, namun ketika hal tersebut digunakan oleh orang jahat, dan bertujuan menimbulkan fitnah dan perpecahan dalam umat, maka dia melarangnya. Hal senada juga disampaikan oleh Abu Zaid, ia memberi batasan bahwa penggunaan ta'wil haruslah berpegang pada perangkat-perangkat analisis teks, dan tidak pada hawa nafsunya atau pendapat pribadinya. Dengan demikian ta'wil tetaplah memiliki posisi yang signifikan dalam proses pembacaan terhadap teks-teks al-Qur'an, dan penggunaan ta'wil sangat membantu dalam pembumian al-Qur'an di tengah kehidupan modern dewasa ini, dan merespon problematika yang ada.

\section{Daftar Pustaka}

Aziz, Amir 'Abdul, 1983. Dirasat fi 'Ulum al-Qur'an, Beirut: Dar al-Furqan.

Baidan, Nashruddin, 2005. Wawasan Baru Ilmu Tafsir, cet. ke-1, Yogyakarta: Pustaka Pelajar.

Ichwan, Moch. Nur, 2002. "al-Qur'an sebagai Teks (Teori Teks dalam Hermeneutik Qur'an Nasr Hamid Abu Zaid)" dalam Abdul Mustaqim dan Sahiron Syamsudin (ed). Studi al-Qur'an Kontemporer Wacana Baru Berbagai Metodologi Tafsir, Yogyakarta: Tiara Wacana.

Isma’il, Muhammad Bakar, 1991. Dirasat fi 'Ulum al-Qur'an, cet. ke-1, Kairo: Dar al-Manar.

Madjid, Nurcholish, "Masalah Ta'wil Sebagai Metodologi Penafsiran alQur'an" dalam http://media.isnet.org/islam/Paramadina/Konteks/ Takwil2.html.Akses 28 November 2016.

Panggabean, Syamsu Rizal, 1990. "Makna Muhkam dan Mutasyabih dalam al-Qur'an” dalam 'Ulumul Qur'an, vol. II, Jakarta: LSAF.

al-Qaradawi, Yusuf, 2000. Kaifa Nata'amalu ma'a al-Qur'an al-Azim?, cet. ke3, Kairo: Dar asy-Syuruq.

al-Qattan, Manna', tt. Mabahis fi 'Ulum al-Qur'an, t.p.: Mansurat al-'Isri alHadis.

as-Salih, Subhi, 1977. Mabahis fi 'Ulum al-Qur'an, cet. ke-7, Beirut: Dar al'Ilm al-Malayin. 


\section{Diskursus Muhkam dan Mutasyabih dalam Tafsir ...}

Shihab, Quraish, Membumikan al-Qur'an, Fungsi dan Peran Wahyu Dalam Kehidupan Masyarakat, cet. ke-23, Jakarta: Mizan, 2002.

Syahrur, Muhammad, 1990. al-Kitab wa al-Qur'an: Qira'ah Mu'asirah, Damaskus: al-Ahaly.

Zaid, Nasr Hamid Abu, 2003. Menalar Firman Tuhan Wacana Majaz dalam al-Qur'an Menurut Mu'tazilah, terj. Abdurrahman Kasdi dan Hamka Hasan, cet. ke-1, Bandung: Mizan. 2002. Tekstualitas al-Qur'an, Kritik Terhadap Ulumul Qur'an, terj. Khoiron Nahdliyyin, Yogyakarta: LKiS.

az-Zarqani, Muhammad 'Abdul 'Azim, 2003. Manahil 'Irfan fi 'Ulum alQur'a>n, cet. ke-1, Beirut: Dar al-'Ilmiyyah. 



\title{
RADIKALISME DAN TERORISME DALAM PERSPEKTIF IJTIHAD PERDAMAIAN NU
}

\author{
Nur Laela \\ Dosen Fakultas Kedokteran (FK)Universitas Jendral Soedirman (UNSOED) \\ Purwokerto Jawa Tengah \\ e-mail: nurlaeladiryat@gmail.co.id
}

\begin{abstract}
Abstrak
Berbicata perspektif ijtihad perdamain NU terdapat lima cara yang menonjol dalam paradigma ber-fiqh yang baru. Pertama, selalu diupayakan interpretasi ulang dalam mengkaji teks-teks fiqh untuk mencari konteksnya yang baru. Kedua, makna bermadzhab diubah dari bermadzhab secara tekstual (madzhab qauli) menjadi bermadzhab secara metodologis (madzhab manhaji). Ketiga, verifikasi mendasar terhadap mana ajaran yang pokok (ushul) dan mana yang cabang (furu'). Keempat, fiqh dihadirkan sebagai etika sosial, bukan sebagai hukum positif negara. Kelima, pengenalan metodologis pemikiran terutama dalam masalah sosial budaya. Dalam hal ini, tulisan ini menggunakan pespektif Nahdlatul Ulama (NU) dalam hal radikalismeterorisme dengan menggunakan pendekatan ushul fiqh dan teori maqashid al-syariah khususnya pada ushul al-khamsah yang dijadikan sebagai tujuan syari'ah dalam tulisan ini. Dalam arti lain bersifat qathii dengan tetap menekankan empat prinsip sikap ijtihad perdamaian, yaitu tasamuh, tawasuth, tawazun, ta'adul.
\end{abstract}

Kata Kunci: terorisme, radikalisme, ushul fiqh, maqashid al-syariah, NU

\section{A. Pendahuluan}

Gerakan radikalisme dan terorisme atas nama agama menjadi fenomena yang dapat dengan mudahnya ditemui pada dewasa ini. Gerakan ini pada prakteknya menimbulkan keresahan dan ketakutan pada masyarakat karena mereka tidak segan menggunakan cara kekerasan dalam mencapai tujuannya. 